\title{
REVIEW
}

SEPTEMBER/ O CTOBER 1997

Michael R. Pakko is an economist at the Federal Reserve Bank of St. Louis. Kelly M. Morris and Eran Segev provided research assistance.

\section{The Business}

Cycle and

Chain-Weighted

GDP: Has Our

Perspective

Changed?

\section{Michael R. Pakko}

n early 1996 the Bureau of Economic Analysis released data from an extensive revision to its measures of aggregate economic activity in the United States. The new data and methodology, which represent the first comprehensive revision of the National Income and Product Accounts (NIPA) since 1991, reflect more substantial changes than have many previous revisions. ${ }^{1}$ W hile past revisions have changed some definitions and statistics and have incorporated newly available source data, the most recent revision includes an even more important change: the move from a fixed base-year measure to a chained index, which is said to have significantly altered the way we view recent economic performance.

One analysis in the $\mathrm{N}$ ew York Times even speculated that the outcome of the 1992 election might have been different if we had known then what we know now about the 1990-91 recession:

The revisions suggest that the downturn of 1990-91 was nearly twice as deep as Washington knew at the time, raising the possibility that the Federal Reserve and the White House would have reacted more aggressively to dig the economy out of a recession. Such a response, coming much earlier than

\section{Figure 1}

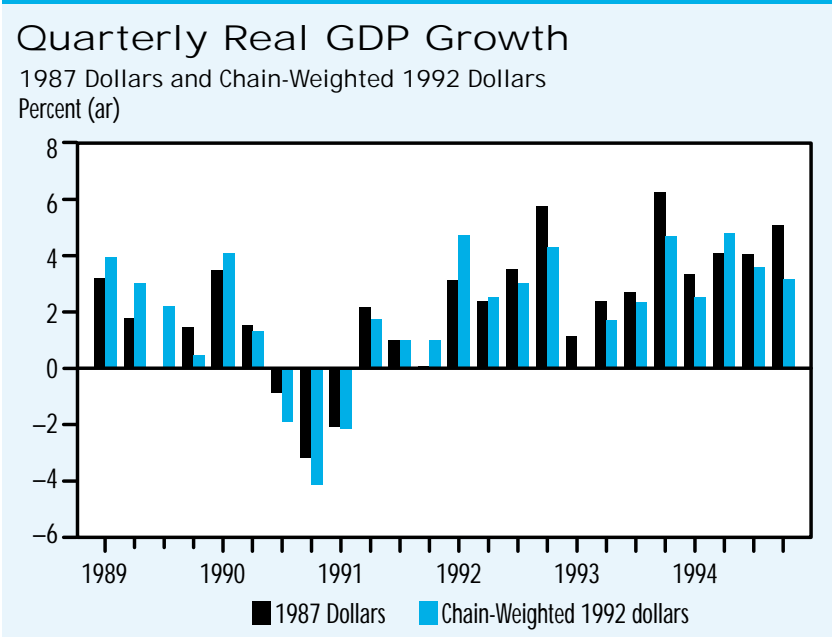

it actually did, might have changed the impression among many voters that President Bush did not care. ${ }^{2}$

Figure 1 illustrates the effect of the changes on the 1990-91 recession and subsequent recovery. During the three quarters of negative economic growth, real GDP registered a 1.8 percent average annual rate of decline under the old methodology. The revised figures show an average rate of decline of more than 2.7 percent. Moreover, the new figures indicate a slower growth rate in the period of economic recovery that followed the recession. The old figures showed a 2.8 percent growth rate from the first quarter of 1991 to the first quarter of 1994, while the new figures indicate 2.5 percent growth.

Two limitations of the old system of measurement have been cited to support the claim of superiority for the new chainweighting approach: First, fixed weights fail to measure the effects of shifting demand in response to relative price changes-known as "substitution bias." Second, the periodic re-basing required by the fixed-weight system of measurement implies a "rewriting of economic history."

\footnotetext{
This was the tenth such "comprehensive" revision. See Parker and Seskin (1996).

2 Passell (1996).

${ }^{3}$ E.g., Samuelson (1996).
} 
But has the revision to NIPA data really changed our view of the fluctuations and economic co-movements known collectively as the "business cycle"? Both casual observation and more rigorous empirical examination reveal that the revisions to GDP and its components have had very little effect on the empirical regularities that characterize economic fluctuations.

After first describing the methodological changes and rationales underlying the recent NIPA data revisions, this article discusses the differences between the revised data and the previously reported data. It then presents a comparison of the basic business cycle regularities as measured under the old and new systems.

\section{REVISIONS TO NIPA DATA}

The revisions to NIPA included new and revised source data, new methodological procedures, the new chain-weighted methodology for reporting real output and its components, and an updated base year. ${ }^{4}$

Some of the more routine changes reflect the incorporation of new and revised source data. For example, the revisions to the data on non-durable consumption expenditures for 1993 and 1994 are based on newly available information on retail sales from the 1993 Annual Retail Trade Survey, while the revisions to data on nondurable goods are based on the results of a 1987 input-output analysis constructed by the Commerce Department. Revisions to the services consumption data are based on direct estimates of rental payments for tenant-occupied dwellings, taken from a 1991 Residential Finance Survey.

In addition, the Commerce department has incorporated some new methodological procedures. For example, it has replaced the previously used straight-line method of estimating depreciation with one based on studies of the prices of used equipment and structures in resale markets.

There are also two significant changes in the classification of government expenditures. Federal Government contributions to civilian and military retirement programs (rather than benefits paid out) are now explicitly reflected in the national accounts. More importantly, government expenditures have been separated into categories for current expenditures and government investment expenditures. The addition of the latter category - which classifies government expenditures for structures and equipment as investmentprovides a more complete measure of investment, including purchases by both the public and private sectors. The change also makes figures for U.S. investment more comparable to those of other countries by treating government investment in a way that is more consistent with the International System of $\mathrm{N}$ ational Accounts.

By far the most significant and widely discussed revision to the NIPA data is the new methodology for reporting real output and its components: the "chained" dollar series. The previously used "constantdollar" measures were based on prices for a specific base year. (Prior to the most recent revision, the base year was 1987.) The new method uses contemporaneous price data to produce estimates of growth rates for real output and its components. The prices are then chained together to form a series that is independent of the choice of any particular base year. This approach mitigates the two related weaknesses of the constant-dollar approach: "substitution bias" and "rewriting economic history."

\section{Substitution Bias}

A fundamental purpose of the new chain-weighting methodology is to avoid the problem known as "substitution bias." As relative prices rise and fall, purchasers tend to substitute less expensive items for ones on which prices have gone up. In a fixed-weight system, items with falling prices continue to constitute a large share of the total, because this system is based on their historically higher prices. Similarly, although sales tend to decline for goods and services items with rising prices, these items continue to have low weights because of their historically lower prices. Consequently, a fixed-weight index tends to overstate growth in periods after the base 


\section{CONSTRUCTION OF CHAIN-WEIGHTED INDEXES}

The purpose of the change to chain-weighting in the NIPA accounts is to improve the separation of price changes and quantity changes in the overall measurement of nominal (current dollar) magnitudes. Specifically, real and nominal measures are related by

$$
\text { Real GDP }=\frac{\text { Nominal GDP }}{P},
$$

where $P$ is some measure of the aggregate price level. Previously, this separation was accomplished by using implicit price deflators to measure P. Implicit price deflators are examples of what is known as a Paasche price index, calculated as follows:

$$
P_{t}^{P}=\frac{\sum_{i=1}^{N} p_{i t} q_{i t}}{\sum_{i=1}^{N} p_{i b} q_{i t}},
$$

where $p$ and $q$ denote quantities and prices, respectively; and the subscripts $t$ and $b$ denote measures in the current period and in a base period, respectively.

An alternative price measure is known as a Laspeyres price index, the formula for which is

$$
P_{t}^{L}=\frac{\sum_{i=1}^{N} p_{i t} q_{i b}}{\sum_{i=1}^{N} p_{i b} q_{i b}} .
$$

Each of these indexes suffers from substitution bias, giving an imperfect measure of the price level. The Laspeyeres index tends to overstate price changes, while the Paasche index tends to understate them.

One way of adjusting for these errors is to take an average of the two. The geometric average of a Laspeyres and a Paasche index is known as a Fisher Index:

$$
P_{t}^{F}=\sqrt{P_{t}^{P} \times P_{t}^{L}}
$$

Although this measure is largely free of systematic substitution bias, it is still subject to the problem of base-year sensitivity. History is rewritten with changes in the base year, since each of the component price indexes uses a fixed base year.

The new chain-weighted GDP accounts use a variant of the Fisher index, in which the base year is not fixed. Instead, the previous year is taken as the base. This makes the price index interpretable as a percentage rate of change from the previous year. The percentage changes can then be "chained" together and expressed either as an index number or in terms of some particular reference period. 


\section{Figure 2}

\section{Real GDP}

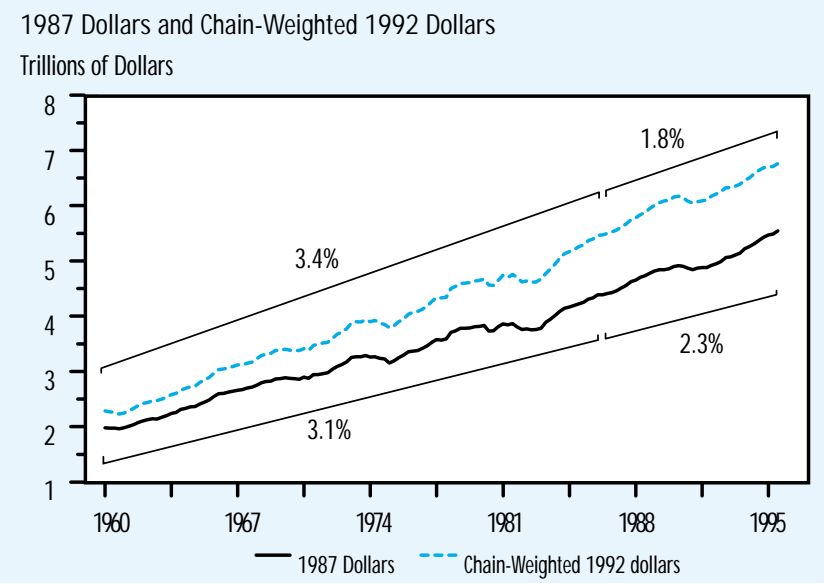

\section{Figure 3}

\section{A Changing View of the 1974-75 Recession} Quarterly Real GNP Growth

Percent Change (ar)

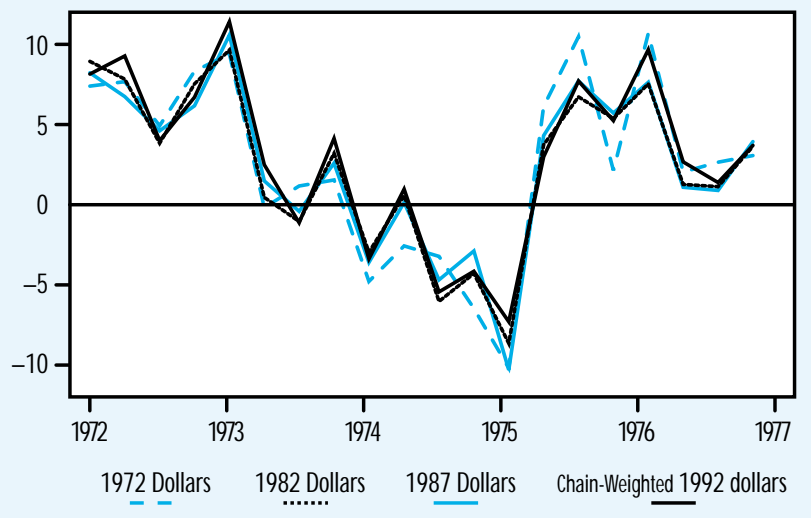

${ }^{5}$ Landefeld (1995).

${ }^{6}$ Jain (1996).

7 Prowse (1996).

${ }^{8}$ Ulan (1994).

9 The BEA switched from GNP to GDP as the featured measure of output in the 1991 comprehensive revisions. Because figures for GDP are unavailable for previous base-year series, GNP is used in Figure 3. prices, caused growth to be overstated. Computers and related equipment were not the only items contributing to this effect, but their role was significant: For instance, it has been estimated that computers accounted for about three-fifths of the 1.1 percentage point overstatement of GDP in the fourth quarter of $1994 .^{5}$

The tendency of the old 1987-dollar GDP series to understate growth before 1987 and to overstate growth after 1987 can be seen in Figure 2, which shows GDP growth from 1960 to 1995.

M easured according to the old fixed-baseyear measure, GDP growth was 3.1 percent before 1987, and 2.3 percent after. With the new chain-weighted measure, the growth rate measures 3.4 percent prior to 1987, and only 1.8 percent after 1987.

\section{Rewriting Economic History}

An additional problem of the old fixed-weight methodology was that rebasing the weights resulted in "rewriting macroeconomic history every 5 years." ${ }^{6}$ For example, one columnist has observed that "each time [the base year] shifts, the 1973-75 recession looks a little different." 7 In general, the effect of the old rebasing has been characterized as providing "a very distorted view of economic history."

Although the new measure continues to be expressed relative to a specific base year-now 1992- the chain-weighting approach makes the choice of a base year nothing more than a matter of normalization. Price and quantity changes are calculated as percentage changes from one year to the next and then "chained" together in a sequence. As a result, future updates of the base year will no longer result in a revised view of the past, because the growth rates on which the chain-weighted figures are based will not be subject to subsequent revision.

Figure 3 illustrates the rewriting of history for one episode- the 1973-75 recession and subsequent recovery. It shows a comparison between the growth rates of real GNP reported at the time of 
the 1973-75 recession and the revised figures after each of three revisions to the base year. ${ }^{9}$ It is clear that each time the NIPA accounts were rebased, the pattern of output growth was revised. However, the most significant change took place in the initial comprehensive revision, which rebased from the original 1972 dollars to 1982 dollars. The subsequent rebasing to 1987 dollars had little additional effect on the pattern of real GNP growth. Perhaps surprisingly, even the chainweighted measure of real GNP growth does not differ markedly from the 1982 or 1987 fixed-weighted measures, in spite of the fact that the chained figures use prices and quantities from the early 1970s, much as the original 1972-based figures did.

Although rebasing changes the pattern of real GDP growth, another important factor in the periodic revision of the NIPA is the incorporation of improved source data. $\mathrm{N}$ ew source data is typically integrated by the time of the first rebasing (or in the annual benchmark revisions), implying noticeable changes to the series. Relative to the original 1972-based data shown in Figure 3, the first base year shows the most significant alteration in the pattern of measured economic activity. Subsequent updates show modest changes. Hence, Figure 3 suggests that revisions to the base year are less important than to the incorporation of new source data in initial benchmark revisions.

Figure 3 also shows that al though the pattern of GNP growth changed from one revision to another, the overall pattern did not change markedly. In particular, the timing of the onset of recession in late 1973 and the recovery in early 1975 was not affected by revisions. History was re-written with each revision, but the fundamental features of that episode in the business cycle remained essentially unchanged. This observation leads naturally to a basic question: Do data revisions- even those as fundamental as the recent switch to chain-weighted GDP-alter our overall perspective on business cycles?

\section{Figure 4}

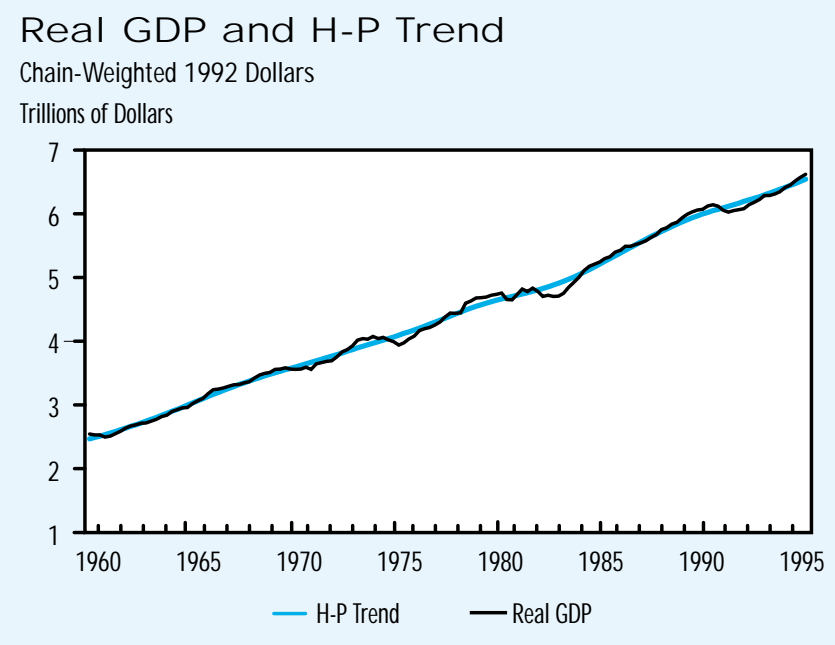

\section{H-P Deviations from Trend}

Percent

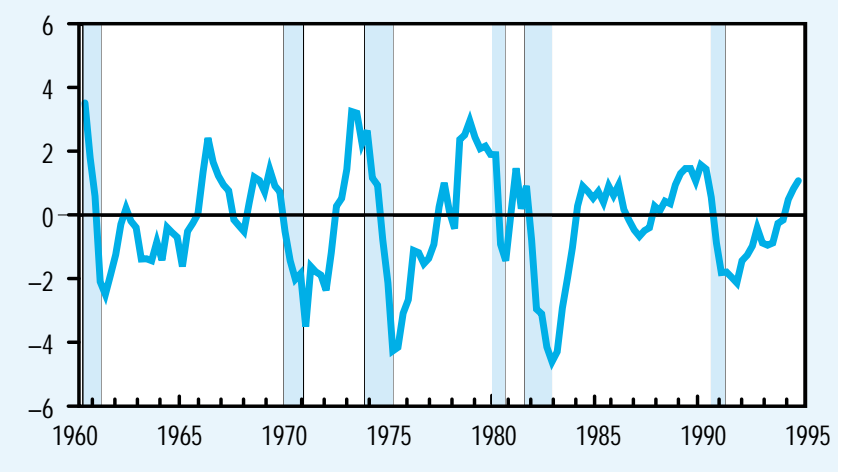

NOTE: Shaded bars indicate recessions.

\section{CYCLICAL PATTERNS UNDER THE OLD AND NEW METHODS}

Each business cycle seems to have its own unique features, yet certain regularities characterize the general nature of economic fluctuations. For various measures of economic activity, key issues about cyclical behavior revolve around the degree of variability, the persistence of fluctuations, and co-movement with other economic indicators. Some economic indicators are more variable than total output, some are less variable; some tend to move in the same direction as output (i.e., they are procyclical) while others tend to move in the opposite direction (countercyclical). These empirical
${ }^{10}$ Formally, the trend component isolated by the H.P filter is given by the equation:

$$
\begin{aligned}
\min & \sum_{t=0}^{T}\left\{\left(y_{t}-y_{t}^{\tau}\right)\right. \\
& +\lambda\left[\left(y_{t+1}^{\tau}-y_{t}^{\tau}\right)\right. \\
& \left.\left.-\left(y_{t}^{\tau}-y_{t-1}^{\tau}\right)\right]^{2}\right\},
\end{aligned}
$$

where $y_{t} \tau$ is the trend component of the time series $y_{t}$, and $\lambda$ is a smoothing parameter. For applications with quarterly economic data, a value of $\lambda=1600$ is typically used. 


\section{Figure 5}

\section{Real GDP Fluctuations}

1987 Dollars and Chain-Weighted 1992 Dollars

Percent

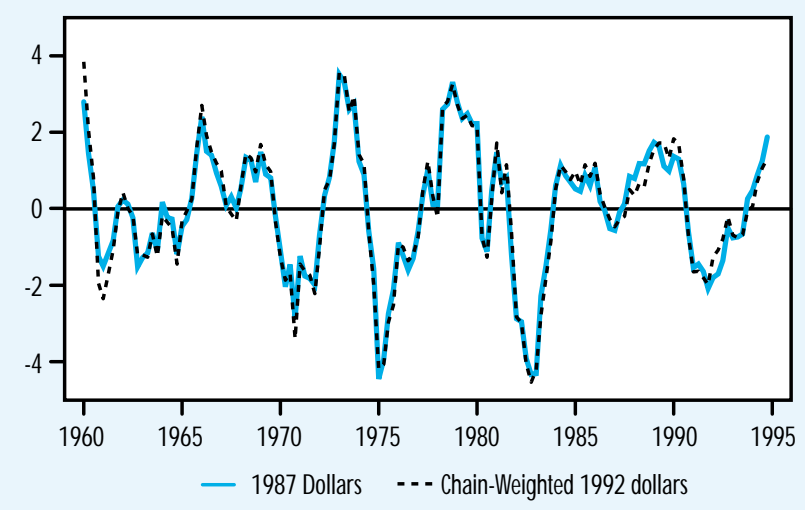

${ }^{11}$ This approach of comparing various "second moments" of time series has been popularized in the "real business cycle" literature; e.g. Kydland and Prescott (1982); King, Plosser, and Rebelo (1988). As in Figures 5 and 6 , the data are logged and detrended by means of the H-P filter. Two series - investment and net exports- are not logged, but taken as a ratio to GDP in order to convert to proportionate measures before detrending.

${ }^{12}$ The countercyclicality of prices is contrary to conventional wisdom and has been an issue of some controversy. See Kydland and Prescott (1992). regularities of business cycles are fundamental to economists' attempts to understand and explain them.

One way of approaching an answer to the question of how revisions affect our understanding of business cycles is to examine various measures and components of output after adjusting for long-term growth trends. This section uses a method of isolating the cyclical components, known as the Hodrick-Prescott (H-P) filter, to examine the cyclical behavior of economic variables. The H-P filter represents a statistical method of fitting a smooth trend line to an economic time series. The deviations from the trend line are then interpreted as the cyclical component of the series. ${ }^{10}$

Figure 4 (p. 43) illustrates a way that the H-P filter separates the trend components from the cyclical components of GDP. Shaded sections in the lower panel of Figure 4 indicate periods of recession as identified by the $\mathrm{N}$ ational Bureau of Economic Research. Note that the periods identified as economic downturns by the $\mathrm{H}-\mathrm{P}$ filtering technique correspond closely to the official recession episodes.

Figure 5 compares the H-P cyclical component of fixed-weighted and chainweighted GDP. It is clear from the figure that the broad pattern of cyclical fluctuations in real GDP is affected very little by the change from fixed-weighted 1987 dollars to chain-weighted 1992 dollars, particularly for the 1970s and early 1980s. To the extent that differences do appear, they occur mostly in the late 1980s and 1990s (where recent benchmark and data-source revisions are important) and in the early 1960s (where fixed 1987 weights are likely to be particularly misleading due to the passage of time).

Figure 6 provides a similar comparison for the major components of GDP. For all four components, the change from fixedweighted to chain-weighted measures makes little discernable difference. In all four cases, revisions to data for the late 1980s and 1990s are most prominent.

Table 1 provides a more formal examination of the behavior of various components of GDP, presenting standard deviations, autocorrelations, and cross correlations with GDP. ${ }^{11}$ The first row of numbers for each variable shows the previously reported statistics based on the fixed-weight measures in 1987 dollars. The second number is the corresponding statistic for chain-weighted 1992 dollars.

The overall patterns are clearly robust to the methodological changes. As measured by standard deviation, consumption of nondurables and services is only about half as variable as output, while durablegoods consumption and investment are about three times as variable. Each of these measures shows a strong positive correlation with output-i.e., each is procyclical. Government spending is about as variable as GDP, and largely uncorrelated to the business cycle. N et exports are countercyclical, due primarily to the strong procyclicality of imports. Under either measurement system, the price level is countercyclical. ${ }^{12}$ These overall patterns are clear for both the fixedweighted and chain-weighted data.

Table 1 (pp. 46-47) also reports probability measures (in italics) for testing the hypothesis that there is any significant difference between the statistics for fixed-weight and chain-weighted figures. ${ }^{13}$ A probability value near zero would indicate that the chain-weighted statistic was significantly less than the fixed-weight statistic, while a value near one 


\section{Figure 6}

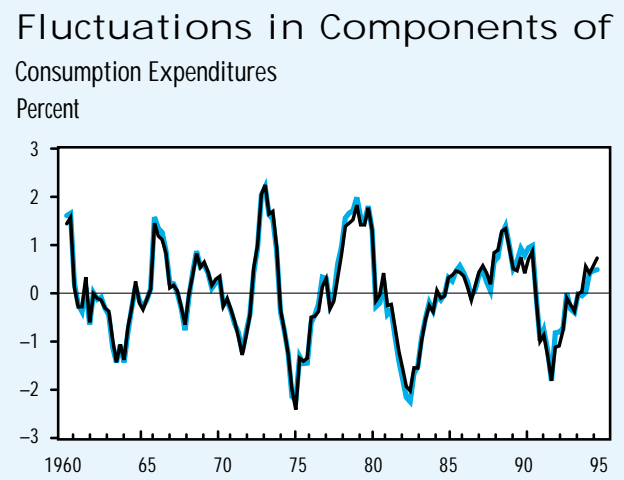

Government Spending

Percent

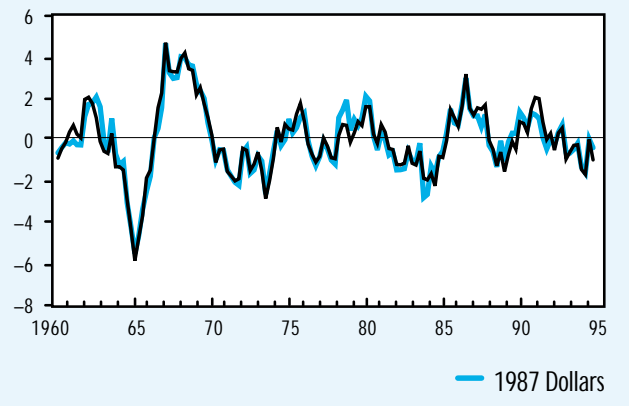

would indicate the opposite. There are no cases at all for which the probability values indicate a statistically significant difference between the measures at conventional significance levels $(<0.05$ or $>0.95)$.

Table 2 (p. 48) provides information on the relationship of the two measures of GDP and other non-NIPA economic indicators. As in Table 1, the differences that arise as a result of the switch to chain-weighting are minor. M easures of employment remain strongly procyclical, while wages and prices are countercyclical. With the exception of non-borrowed reserves, measures of money (including total reserves, the monetary base, $M 1$ and M2) are procyclical. None of the comparisons between the fixed-weight method and chain-weighting in Table 2 is statistically significant.

\section{CONCLUSION}

The new chain-weighted GDP measure is conceptually superior to the old fixed-weight index. Most importantly, the chain-weighting approach corrects for the "substitution bias" in which measures of long-term growth become increasingly distorted as they move away from a fixed base year. It also resolves the issue of "rewriting history" every time there is a comprehensive revision to the national accounts. However, the switch to the new approach has little or no effect on an overall evaluation of the fluctuations and comovements among economic variables that constitute the business cycle.
${ }^{13}$ The probability values for differences in standard deviations are derived from standard F-tests. For autocorrelations and crosscorrelations with GDP, the reported statistic is based on

$$
\begin{aligned}
& Z=\frac{\sqrt{N-3}}{2 \sqrt{2}} \\
& \mathrm{x}\left[\ln \left(\frac{1+\rho_{i}}{1-\rho_{i}}\right)\right. \\
& \left.-\ln \left(\frac{1+\rho_{j}}{1-\rho_{j}}\right)\right],
\end{aligned}
$$

which is normally distributed under the hypothesis that the correlations, $\rho_{\mathrm{i}}$ and $\rho_{\mathrm{j}}$, are identical. 


\section{Table 1}

\section{Comparisons of the Cyclical Properties of NIPA Data}

1987 Dollars and Chained 1992 Dollars - H-P Filtered

\begin{tabular}{|c|c|c|c|c|c|c|}
\hline \multirow[b]{2}{*}{ Variable } & \multicolumn{2}{|c|}{ Standard Deviations } & \multicolumn{4}{|c|}{ Autocorrelations } \\
\hline & Percent & Ratio to GDP & 1 & 2 & 3 & 4 \\
\hline \multirow[t]{3}{*}{ GDP } & 1.63 & 1.00 & 0.85 & 0.65 & 0.43 & 0.23 \\
\hline & 1.71 & 1.00 & 0.84 & 0.62 & 0.39 & 0.19 \\
\hline & 0.611 & & 0.614 & 0.661 & 0.655 & 0.635 \\
\hline \multirow{3}{*}{$\begin{array}{c}\text { Consumption } \\
\text { Nondurables } \\
\text { plus services }\end{array}$} & 0.84 & 0.52 & 0.86 & 0.67 & 0.50 & 0.28 \\
\hline & 0.87 & 0.51 & 0.86 & 0.68 & 0.50 & 0.29 \\
\hline & 0.582 & & 0.500 & 0.440 & 0.500 & 0.464 \\
\hline \multirow{3}{*}{$\begin{array}{l}\text { Consumption } \\
\text { Services }\end{array}$} & 0.68 & 0.42 & 0.80 & 0.62 & 0.46 & 0.29 \\
\hline & 0.71 & 0.41 & 0.82 & 0.65 & 0.50 & 0.32 \\
\hline & 0.600 & & 0.315 & 0.339 & 0.333 & 0.392 \\
\hline \multirow{3}{*}{$\begin{array}{c}\text { Consumption } \\
\text { Nondurables }\end{array}$} & 1.20 & 0.74 & 0.84 & 0.63 & 0.43 & 0.20 \\
\hline & 1.24 & 0.72 & 0.84 & 0.62 & 0.41 & 0.18 \\
\hline & 0.576 & & 0.500 & 0.554 & 0.580 & 0.568 \\
\hline \multirow{3}{*}{$\begin{array}{l}\text { Consumption } \\
\text { Durables }\end{array}$} & 5.01 & 3.08 & 0.76 & 0.60 & 0.40 & 0.23 \\
\hline & 5.01 & 2.93 & 0.77 & 0.60 & 0.41 & 0.24 \\
\hline & 0.500 & & 0.421 & 0.500 & 0.461 & 0.465 \\
\hline \multirow{3}{*}{$\begin{array}{l}\text { Fixed } \\
\text { nonresidential } \\
\text { investment }\end{array}$} & 5.22 & 3.21 & 0.89 & 0.71 & 0.48 & 0.23 \\
\hline & 5.00 & 2.93 & 0.89 & 0.70 & 0.46 & 0.21 \\
\hline & 0.400 & & 0.500 & 0.565 & 0.584 & 0.569 \\
\hline \multirow{3}{*}{$\begin{array}{l}\text { Change in } \\
\text { business } \\
\text { inventories }\end{array}$} & 0.52 & 0.32 & 0.43 & 0.17 & 0.01 & -0.15 \\
\hline & 0.47 & 0.27 & 0.46 & 0.18 & 0.02 & -0.14 \\
\hline & 0.276 & & 0.378 & 0.466 & 0.467 & 0.466 \\
\hline \multirow{3}{*}{$\begin{array}{l}\text { Government } \\
\text { purchases }\end{array}$} & 1.65 & 1.02 & 0.86 & 0.72 & 0.58 & 0.43 \\
\hline & 1.63 & 0.95 & 0.85 & 0.70 & 0.58 & 0.43 \\
\hline & 0.471 & & 0.621 & 0.631 & 0.500 & 0.500 \\
\hline \multirow[t]{3}{*}{ Exports } & 4.37 & 2.69 & 0.64 & 0.52 & 0.38 & 0.22 \\
\hline & 4.38 & 2.56 & 0.62 & 0.51 & 0.37 & 0.19 \\
\hline & 0.505 & & 0.608 & 0.545 & 0.538 & 0.602 \\
\hline \multirow[t]{3}{*}{ Imports } & 5.14 & 3.16 & 0.75 & 0.54 & 0.35 & 0.18 \\
\hline & 5.29 & 3.09 & 0.74 & 0.54 & 0.37 & 0.21 \\
\hline & 0.567 & & 0.574 & 0.500 & 0.425 & 0.398 \\
\hline \multirow[t]{3}{*}{ Net exports } & 0.50 & 0.31 & 0.89 & 0.76 & 0.64 & 0.49 \\
\hline & 0.44 & 0.26 & 0.87 & 0.73 & 0.62 & 0.46 \\
\hline & 0.226 & & 0.769 & 0.712 & 0.608 & 0.626 \\
\hline \multirow[t]{3}{*}{ Price deflator } & 0.89 & 0.55 & 0.91 & 0.79 & 0.64 & 0.46 \\
\hline & 0.89 & 0.52 & 0.93 & 0.81 & 0.66 & 0.48 \\
\hline & 0.500 & & 0.139 & 0.323 & 0.387 & 0.416 \\
\hline
\end{tabular}

NOTE: The first row of numbers for each variable refers to 1987 dollars, the second to chainweighted 1993 dollars, and the third (in italics) is a normal test statistic, extreme values of which represent rejection of the hypothesis that the two measures are equal (see text). 


\section{Comparisons of The Cyclical Properties of NIPA Data}

\section{Dollars and Chained 1992 Dollars - H-P Filtered}

\begin{tabular}{|c|c|c|c|c|c|c|c|c|c|c|c|}
\hline & & & & Cross- & Correlation & $s$ with $Y(t$ & & & & & \\
\hline & 12 & 8 & 4 & 2 & 1 & 0 & -1 & -2 & -4 & -8 & -12 \\
\hline GDP & -0.47 & -0.33 & 0.23 & 0.65 & 0.85 & 1.00 & 0.85 & 0.65 & 0.23 & -0.33 & -0.47 \\
\hline & -0.42 & -0.32 & 0.19 & 0.62 & 0.84 & 1.00 & 0.84 & 0.62 & 0.19 & -0.32 & -0.42 \\
\hline & 0.303 & 0.463 & 0.635 & 0.661 & 0.614 & NA & 0.614 & 0.661 & 0.635 & 0.463 & 0.303 \\
\hline Consumption & -0.41 & -0.32 & 0.17 & 0.56 & 0.73 & 0.86 & 0.83 & 0.71 & 0.37 & -0.24 & -0.42 \\
\hline plus services & -0.40 & -0.32 & 0.12 & 0.52 & 0.71 & 0.84 & 0.81 & 0.69 & 0.37 & -0.20 & -0.39 \\
\hline & 0.461 & 0.500 & 0.664 & 0.680 & 0.635 & 0.725 & 0.693 & 0.627 & 0.500 & 0.364 & 0.383 \\
\hline Consumption & -0.46 & -0.24 & 0.21 & 0.51 & 0.65 & 0.80 & 0.79 & 0.69 & 0.36 & -0.24 & -0.45 \\
\hline Services & -0.46 & -0.24 & 0.18 & 0.49 & 0.64 & 0.76 & 0.77 & 0.67 & 0.38 & -0.19 & -0.41 \\
\hline & 0.500 & 0.500 & 0.602 & 0.587 & 0.556 & 0.802 & 0.664 & 0.621 & 0.424 & 0.332 & 0.342 \\
\hline Consumption & -0.34 & -0.35 & 0.12 & 0.53 & 0.71 & 0.82 & 0.77 & 0.65 & 0.34 & -0.20 & -0.35 \\
\hline Nondurables & -0.30 & -0.34 & 0.06 & 0.49 & 0.68 & 0.80 & 0.75 & 0.63 & 0.32 & -0.19 & -0.33 \\
\hline & 0.356 & 0.463 & 0.692 & 0.673 & 0.685 & 0.685 & 0.652 & 0.610 & 0.574 & 0.466 & 0.426 \\
\hline & -0.43 & -0.52 & -0.08 & 0.38 & 0.59 & 0.80 & 0.77 & 0.68 & 0.47 & -0.05 & -0.29 \\
\hline Durables & -0.40 & -0.50 & -0.08 & 0.39 & 0.61 & 0.81 & 0.78 & 0.67 & 0.44 & -0.06 & -0.29 \\
\hline & 0.382 & 0.411 & 0.500 & 0.461 & 0.398 & 0.407 & 0.418 & 0.560 & 0.623 & 0.533 & 0.500 \\
\hline & -0.53 & -0.28 & 0.49 & 0.79 & 0.85 & 0.80 & 0.60 & 0.36 & -0.05 & -0.40 & -0.33 \\
\hline nonresidential & -0.50 & -0.28 & 0.45 & 0.78 & 0.85 & 0.81 & 0.60 & 0.35 & -0.07 & -0.40 & -0.32 \\
\hline & 0.368 & 0.500 & 0.665 & 0.585 & 0.500 & 0.407 & 0.500 & 0.538 & 0.566 & 0.500 & 0.463 \\
\hline Change in & -0.17 & -0.41 & -0.15 & 0.20 & 0.42 & 0.61 & 0.44 & 0.33 & 0.12 & 0.00 & -0.14 \\
\hline business & -0.13 & -0.40 & -0.16 & 0.18 & 0.42 & 0.65 & 0.50 & 0.37 & 0.12 & 0.00 & -0.12 \\
\hline & 0.367 & 0.461 & 0.534 & 0.568 & 0.500 & 0.291 & 0.262 & 0.353 & 0.500 & 0.500 & 0.433 \\
\hline Government & -0.02 & 0.40 & 0.34 & 0.18 & 0.13 & 0.08 & -0.01 & -0.07 & -0.14 & -0.18 & -0.12 \\
\hline & -0.08 & 0.35 & 0.37 & 0.26 & 0.22 & 0.16 & 0.05 & -0.03 & -0.12 & -0.22 & -0.16 \\
\hline & 0.691 & 0.685 & 0.388 & 0.243 & 0.221 & 0.251 & 0.310 & 0.370 & 0.433 & 0.635 & 0.632 \\
\hline Exports & -0.03 & 0.29 & 0.47 & 0.45 & 0.41 & 0.27 & 0.05 & -0.18 & -0.43 & -0.49 & -0.10 \\
\hline & -0.09 & 0.23 & 0.42 & 0.45 & 0.42 & 0.29 & 0.10 & -0.12 & -0.36 & -0.45 & -0.10 \\
\hline & 0.691 & 0.703 & 0.697 & 0.500 & 0.460 & 0.429 & 0.339 & 0.306 & 0.246 & 0.335 & 0.500 \\
\hline Imports & -0.42 & -0.52 & 0.06 & 0.48 & 0.70 & 0.75 & 0.65 & 0.50 & 0.28 & -0.09 & -0.30 \\
\hline & -0.38 & -0.48 & 0.03 & 0.45 & 0.68 & 0.75 & 0.66 & 0.51 & 0.29 & -0.06 & -0.30 \\
\hline & 0.347 & 0.329 & 0.598 & 0.624 & 0.624 & 0.500 & 0.442 & 0.456 & 0.464 & 0.401 & 0.500 \\
\hline Net exports & 0.39 & 0.64 & 0.24 & -0.12 & -0.31 & -0.44 & -0.51 & -0.53 & -0.52 & -0.29 & 0.14 \\
\hline & 0.33 & 0.57 & 0.21 & -0.12 & -0.31 & -0.43 & -0.49 & -0.50 & -0.48 & -0.26 & 0.15 \\
\hline & 0.716 & 0.820 & 0.603 & 0.500 & 0.500 & 0.459 & 0.413 & 0.368 & 0.329 & 0.394 & 0.466 \\
\hline Price deflator & 0.51 & 0.49 & -0.04 & -0.34 & -0.46 & -0.58 & -0.67 & -0.72 & -0.64 & -0.10 & 0.35 \\
\hline & 0.48 & 0.49 & -0.07 & -0.40 & -0.55 & -0.66 & -0.70 & -0.70 & -0.56 & -0.06 & 0.34 \\
\hline & 0.629 & 0.500 & 0.598 & 0.718 & 0.842 & 0.860 & 0.680 & 0.369 & 0.150 & 0.369 & 0.537 \\
\hline
\end{tabular}




\section{Cross-Correlations of Non-NIPA Variables with GDP}

\begin{tabular}{|c|c|c|c|c|c|c|c|c|c|c|c|}
\hline \multirow[b]{2}{*}{ Variable } & \multirow[b]{2}{*}{12} & \multirow[b]{2}{*}{8} & \multirow[b]{2}{*}{4} & \multicolumn{3}{|c|}{ Cross-Correlations with $Y(t+j)$} & \multirow{2}{*}{-1} & \multirow[b]{2}{*}{-2} & \multirow[b]{2}{*}{-4} & \multirow[b]{2}{*}{-8} & \multirow[b]{2}{*}{-12} \\
\hline & & & & 2 & 1 & 0 & & & & & \\
\hline \multirow[t]{3}{*}{ Employment } & -0.45 & -0.17 & 0.55 & 0.83 & 0.90 & 0.84 & 0.64 & 0.42 & 0.03 & -0.44 & -0.4 \\
\hline & -0.43 & -0.18 & 0.51 & 0.81 & 0.88 & 0.82 & 0.63 & 0.41 & 0.02 & -0.41 & -0.44 \\
\hline & 0.419 & 0.534 & 0.677 & 0.693 & 0.788 & 0.703 & 0.555 & 0.540 & 0.533 & 0.381 & 0.377 \\
\hline \multirow[t]{3}{*}{ Average w eekly hours } & -0.26 & -0.48 & -0.09 & 0.34 & 0.60 & 0.77 & 0.71 & 0.55 & 0.23 & -0.25 & -0.23 \\
\hline & -0.24 & -0.48 & -0.12 & 0.32 & 0.58 & 0.77 & 0.72 & 0.57 & 0.23 & -0.24 & -0.20 \\
\hline & 0.430 & 0.500 & 0.599 & 0.574 & 0.600 & 0.500 & 0.433 & 0.405 & 0.500 & 0.465 & 0.397 \\
\hline Total w ork effort & -0.44 & -0.3 & 0.41 & 0.76 & 0.89 & 0.91 & 0.75 & 0.52 & 0.09 & -0.45 & -0.43 \\
\hline \multirow[t]{2}{*}{ (Employment x Hours) } & -0.42 & -0.31 & 0.38 & 0.74 & 0.87 & 0.9 & 0.75 & 0.53 & 0.09 & -0.43 & -0.41 \\
\hline & 0.420 & 0.536 & 0.616 & 0.647 & 0.769 & 0.676 & 0.500 & 0.455 & 0.500 & 0.419 & 0.420 \\
\hline \multirow[t]{3}{*}{ Average hourly earnings } & 0.29 & 0.16 & -0.04 & -0.17 & -0.23 & -0.28 & -0.39 & -0.47 & -0.49 & -0.26 & 0.10 \\
\hline & 0.27 & 0.12 & -0.05 & -0.16 & -0.21 & -0.25 & -0.35 & -0.43 & -0.46 & -0.25 & 0.11 \\
\hline & 0.571 & 0.632 & 0.533 & 0.466 & 0.431 & 0.395 & 0.351 & 0.339 & 0.374 & 0.465 & 0.467 \\
\hline \multirow[t]{3}{*}{ CPI } & 0.46 & 0.54 & 0.11 & -0.25 & -0.42 & -0.59 & -0.71 & -0.77 & -0.70 & -0.18 & 0.33 \\
\hline & 0.44 & 0.50 & 0.11 & -0.23 & -0.39 & -0.55 & -0.68 & -0.73 & -0.67 & -0.17 & 0.30 \\
\hline & 0.582 & 0.675 & 0.500 & 0.430 & 0.383 & 0.312 & 0.315 & 0.224 & 0.320 & 0.466 & 0.609 \\
\hline \multirow[t]{3}{*}{ Nonborrow ed reserves } & 0.09 & 0.19 & -0.21 & -0.29 & -0.27 & -0.18 & -0.01 & 0.15 & 0.27 & 0.27 & 0.02 \\
\hline & 0.08 & 0.21 & -0.17 & -0.29 & -0.29 & -0.20 & -0.05 & 0.10 & 0.22 & 0.24 & 0.04 \\
\hline & 0.533 & 0.432 & 0.366 & 0.500 & 0.571 & 0.568 & 0.630 & 0.663 & 0.670 & 0.605 & 0.434 \\
\hline \multirow[t]{3}{*}{ Total reserves } & -0.07 & 0.04 & -0.03 & 0.03 & 0.09 & 0.17 & 0.24 & 0.27 & 0.23 & 0.04 & -0.07 \\
\hline & -0.05 & 0.07 & -0.01 & 0.03 & 0.07 & 0.13 & 0.19 & 0.21 & 0.17 & 0.01 & -0.03 \\
\hline & 0.434 & 0.402 & 0.434 & 0.500 & 0.566 & 0.633 & 0.668 & 0.701 & 0.698 & 0.598 & 0.370 \\
\hline \multirow[t]{3}{*}{ Monetary base } & -0.19 & 0.04 & 0.11 & 0.25 & 0.30 & 0.36 & 0.32 & 0.26 & 0.16 & -0.09 & -0.20 \\
\hline & -0.18 & 0.08 & 0.12 & 0.23 & 0.26 & 0.31 & 0.26 & 0.19 & 0.14 & -0.08 & -0.20 \\
\hline & 0.466 & 0.370 & 0.467 & 0.570 & 0.640 & 0.679 & 0.706 & 0.729 & 0.567 & 0.467 & 0.500 \\
\hline \multirow[t]{3}{*}{ M1 } & -0.09 & -0.06 & -0.04 & 0.09 & 0.19 & 0.30 & 0.36 & 0.36 & 0.28 & 0.05 & -0.19 \\
\hline & -0.06 & -0.01 & -0.03 & 0.08 & 0.16 & 0.25 & 0.30 & 0.30 & 0.21 & 0.03 & -0.15 \\
\hline & 0.401 & 0.339 & 0.467 & 0.533 & 0.601 & 0.673 & 0.711 & 0.711 & 0.731 & 0.566 & 0.367 \\
\hline \multirow[t]{3}{*}{ M2 } & -0.14 & -0.40 & -0.26 & 0.03 & 0.20 & 0.39 & 0.52 & 0.57 & 0.48 & 0.06 & -0.26 \\
\hline & -0.13 & -0.39 & -0.26 & 0.04 & 0.22 & 0.40 & 0.53 & 0.57 & 0.48 & 0.05 & -0.26 \\
\hline & 0.466 & 0.461 & 0.500 & 0.467 & 0.431 & 0.461 & 0.455 & 0.500 & 0.500 & 0.533 & 0.500 \\
\hline \multirow[t]{3}{*}{ 3-month T-bill rate } & -0.04 & 0.22 & 0.48 & 0.48 & 0.45 & 0.34 & 0.08 & -0.21 & -0.55 & -0.58 & -0.09 \\
\hline & -0.05 & 0.18 & 0.43 & 0.46 & 0.43 & 0.34 & 0.10 & -0.17 & -0.52 & -0.55 & -0.08 \\
\hline & 0.533 & 0.635 & 0.699 & 0.584 & 0.581 & 0.500 & 0.434 & 0.366 & 0.364 & 0.358 & 0.467 \\
\hline
\end{tabular}

NOTE: See note to Table 1. 


\section{REFERENCES}

Jain, P. "Feature: The Chain-weighted GDP Measure," Prudential Economics (January 1996), pp. 14-17.

King, Robert G., Charles I. Plosser, and Sergio T. Rebelo. "Production, Growth and Business Cycles: I. The Basic Neoclassical Model," Journal of Monetary Economics (1988), pp. 195-232.

Kydland, Finn E, and Edward C. Prescott. "Business Cycles: Real Facts and a Monetary Myth," Quarterly Review, Federal Reserve Bank of Minneapolis (Spring 1990), pp. 3-18.

and
Econometrica (1982), "pp. 1345-70.

Landefeld, J. Steven. "BEA's Featured Measure of Output and Prices," NABE News 113 (September 1995).

Parker, Robert P., and Eugene P. Seskin. "Improved Estimates of the National Income and Product Accounts for 1959-95: Results of the Comprehensive Revision," Survey of Current Business, (January/ February 1996), pp. 1-31.

Passell, Peter. "Maybe It Wasn't the Economy in the 1992 Election," New York Times, Jan. 20, 1996.

Prowse, Michael. "Lies, Damned Lies, and the US Commerce Department's New Way of Measuring GDP," Financial Times, Jan. 20-21, 1996.

Samuelson, Robert ]. "Rewriting Economic History," The Washington Post, Feb. 28, 1996.

Ulan, Michael. "Is the Current Business Cycle Different? Does How We Measure Matter?" Business Economics (April 1994), pp. 41-47.

United States Department of Commerce- Bureau of Economic Analysis, "Gross Domestic Product: Third Quarter 1995 (preliminary); Corporate Profits, Third Quarter 1995 (preliminary); and Revised Estimates, 1959-95," Survey of Current Business (November/ December 1995), pp. 1-47. 